\title{
Behavioural evidence for a putative oviposition-deterring pheromone in the butterfly, Phengaris (Maculinea) teleius (Lepidoptera: Lycaenidae)
}

\author{
MARCIN SIELEZNIEW ${ }^{1 *}$ and ANNA M. STANKIEWICZ-FIEDUREK ${ }^{2}$ \\ ${ }^{1}$ Department of Applied Entomology, Warsaw University of Life Sciences (SGGW), Nowoursynowska 159, PL-02-776 Warszawa, \\ Poland \\ ${ }^{2}$ Laboratory of Social and Myrmecophilous Insects, Museum and Institute of Zoology, Polish Academy of Sciences, Wilcza 62, \\ PL-00-679 Warszawa, Poland
}

Key words. Host plant marking behaviour, host plant selection, Maculinea teleius, myrmecophily, oviposition, oviposition-deterring pheromone, Phengaris teleius, Sanguisorba officinalis, social parasite

\begin{abstract}
Larvae of the endangered Scarce Large Blue butterfly, Phengaris (Maculinea) teleius, are initially endophytic, feeding upon developing seeds of Sanguisorba officinalis, but complete their development as social parasites preying on the brood of Myrmica ants. Females show very specific preferences, laying eggs exclusively in young flower heads of the food plant. In the present contribution we report the results of a detailed study of female behaviour at three sites differing in size and abundance of $S$. officinalis. Tracked individuals switched between feeding on nectar (nectaring), flight and oviposition. They fed exclusively on flowers of reddish, pink or violet colouration, favouring Viccia cracca and S. officinalis. However, females spent about one fifth of the time they were active ovipositing and laid about 20 eggs per hour. Oviposition visits to flower heads were highly stereotyped and followed a specific ritual. Examination of accepted, rejected and randomly sampled flower heads showed that females avoided those containing conspecific eggs and at a site where this was difficult due to a shortage of suitable flower heads, they tended to distribute their eggs evenly among the available flower heads. Our results indirectly indicate the existence of an oviposition-deterring pheromone (ODP) in P. teleius. This hypothetical marking ensures a more even distribution of eggs and possibly increases the chances of survival of caterpillars by reducing competition during both the phytophagous and myrmecophagous stages of development. There are few reports of butterflies producing ODPs and to our knowledge this is the first evidence of their presence in the family Lycaenidae.
\end{abstract}

\section{INTRODUCTION}

Many phytophagous animals show a high level of specialization in terms of their food resources (Jaenike, 1990). This is well illustrated by the larvae of holometabolous insects, e.g. Lepidoptera, whose caterpillars often feed only on a few species of plants belonging to a single family (oligophagous), or even genus (monophagous). Striking examples of such relationships can be found among European butterflies, whose food plant preferences are relatively well known (Tolman \& Lewington, 2009). Some representatives of this group depend on one plant species. Moreover, caterpillars often prefer only certain parts of host plants, e.g. young leaves, inflorescence or developing seeds (Munguira et al., 2009).

Insect-plant relationships are usually initiated by an ovipositing female, which responds to a variety of stimuli (Thompson \& Pellmyr, 1991; Renwick \& Chew, 1994). Some females seem to be quite careless and simply lay their eggs on the ground, or even on substrates that are not appropriate food sources. There are examples of such behaviour among species overwintering as eggs, the caterpillars of which feed on herbaceous plants appearing only for a short time in spring, or when the larval food plants (e.g. grasses) are relatively numerous in turf (Wik- lund, 1984). Even then females select the proper type of vegetation, orienting to visual and chemical cues. However, most females are much more precise and oviposit only on stems, young shoots, the under-side / upper-side of leaves, buds or flowers of specific plants (GarcíaBarros \& Fartmann, 2009). Certain individual plants may attract the attention of many females because of specific favourable microclimatic conditions e.g. Euphydryas aurinia (Rott.) in wet meadows prefer Succisa pratensis L. plants growing in places most appropriate for their caterpillars, which live gregariously and bask (Porter, 1982). Allomones may also provide important cues, e.g. for myrmecophilous species, i.e. some lycaenids and riodinids (Pierce \& Elgar, 1985; DeVries \& Penz, 2000; Pierce et al., 2002). Oviposition is also sometimes influenced directly or indirectly by infestations of other insects (Árnyas et al., 2009).

Some pierids and nymphalid butterflies lay their eggs in batches. In these cases, the host plants are relatively large and/or the caterpillars are mobile and therefore able to avoid competition. On the other hand, many larvae are sedentary and feed individually on relatively small herbaceous plants. Moreover, finding new resources is difficult when plants are scattered within a habitat (García-Barros

\footnotetext{
* Corresponding and present address: Department of Invertebrate Zoology, Institute of Biology, University of Bialystok, Świer-
} kowa 20B, PL-15-950 Bialystok, Poland; e-mail: marcins@uwb.edu.pl 
\& Fartmann, 2009). For caterpillars feeding on inflorescences, even movements between flowers or flower heads may be difficult because of long stems. Therefore two factors are vital for successful development, i.e. initial quality of food resource and little or no competition. The latter a female can achieve by looking for space free of conspecific eggs or larvae and by preventing the subsequent oviposition by other females (Thompson \& Pellmyr, 1991).

Many insects use oviposition-deterring pheromones (ODPs) to secure an abundance of food for their offspring. These chemicals may be deposited by females, associated with eggs or produced by larvae. Examples of chemical marking are common among e.g. beetles and hymenopterans (Roitberg \& Prokopy, 1987; Nufio \& Papaj, 2001; Anderson, 2002). However, there is very little evidence of such a strategy among Lepidoptera, and butterflies in particular (Renwick \& Chew, 1994; GarcíaBarros \& Fartmann, 2009). The existence of ODPs is proven only for Pieris brassicae (L.) (Rothschild \& Schoonhoven, 1977), P. rapae (L.) (Schoonhoven et al., 1990a) and Anthocharis cardamines (L.) (Dempster, 1992). Eggs laid by conspecific females may also be detected visually, as is reported for P. brassicae (Schoonhoven et al., 1990b) and finally chemicals emitted from leaves damaged by caterpillars may deter females (Sato et al., 1999).

In this study, we tested the hypothesis that in the Scarce Large Blue Phengaris (Maculinea) teleius (Bgstr.) (Lepidoptera: Lycaenidae) intra-specific signalling i.e. the presence of previously laid eggs, is the key factor determining a female's decision to oviposit or not. The ecology of butterflies of the genus Phengaris Doherty (the senior synonym of Maculinea van Eecke, see Fric et al., 2007) is well studied in Europe (Settele et al., 2005). They have attracted the attention of scientists and the public because of their conservation status and unique and complicated life history (Settele \& Thomas, 2004). Their immature stages require two vital resources, i.e., specific plants on which the caterpillars initially feed, and specific ants in whose nests larvae continue their development as social parasites and finally pupate (Thomas et al., 1995). There is an ongoing discussion as to whether females are able to detect host ants or if they select only a particular type of vegetation structure (Fürst \& Nash, 2010; Van Dyck \& Regniers, 2010; Patricelli et al., 2011 and references therein). In the present paper we show that as far as $P$. teleius is concerned other cues may be also important. Moreover, by comparing female behaviour in biotopes differing in the abundance of larval food plants, we evaluated whether $P$. teleius was able to adjust to differences in availability of resources.

\section{MATERIAL AND METHODS}

\section{Study species}

Phengaris (Maculinea) teleius (Bergsträsser, 1779) is a Palearctic species distributed from Japan through Asia and Central Europe to France. In the north it only sometimes reaches $50^{\circ} \mathrm{N}$. Despite its vast range its occurrence is usually very local due to its specific habitat requirements. Typically P. teleius inhabits wet meadows and margins of fens, often in river valleys, preferring Molinion or wetter Arrhenaterion vegetation and their early successional stages (Filipendulion). The species is endangered in many countries and listed in Appendices II and IV of the Habitats' Directive (Wynhoff, 1996; van Swaay \& Warren, 1999; Wynhoff, 2001).

Adults are on the wing from mid June to early September, depending on locality, with the peak of abundance falling usually in late July (Wynhoff, 1996). Average life span is rather short but asynchronic emergence results in a long flight period (Nowicki et al., 2005b). Females oviposit exclusively on flower heads of Sanguisorba officinalis L. at a particular developmental stage i.e. they prefer young ones, which are shorter, closer to the ground, and still in bud, i.e., most of the flowers are covered by green sepals. Flat shaped and thin-shelled eggs are laid singly in flower heads, which makes difficult to see them without dissection (Thomas, 1984; Figurny \& Woyciechowski, 1998; Stettmer et al., 2001).

Hatchling caterpillars feed on flowers and developing seeds in flower heads. They grow relatively slowly, and after about three weeks at the beginning of the fourth and final instar reach about 4-6 mg, i.e. only about $2-4 \%$ of their final larval body mass. Then the caterpillars leave the flower heads and drop to the ground where when encountered by a foraging worker ant of Myrmica Latr. are transported to a colony after a specific adoption ritual. There they feed on the ants' brood and after ten months pupate (Thomas, 1984). Development of some larvae may take two years (growth polymorphism) (Witek et al., 2006). Relationships with ants used to be considered as highly specific to M. scabrinodis Nyl. (Thomas et al., 1989). However, recent studies show that $P$. teleius is a generalist and its larvae may also develop in the nests of other Myrmica species (Stankiewicz \& Sielezniew, 2002; Tartally \& Varga, 2008; Witek et al., 2008, 2010). At most sites the most important factor is the availability of host ants, rather than host plants, which are usually abundant (Elmes \& Thomas, 1992; Wynhoff et al., 2008; Van Langevelde \& Wynhoff, 2009).

\section{Study sites}

Studies were carried out in Poland, where P. teleius is not yet threatened (Buszko et al., 2005), at three sites differing in size, vegetation structure and abundance of resources (Table 1). Two of them (Bielany and Powsinek) are in the outskirts of Warsaw (northern and southern districts respectively) and the third site (Kosyń) in the Polesie region (Lubelska Upland), in the eastern part of the country.

In Warsaw, populations of $P$. teleius were rather isolated and biotopes consisted of Filipendulo-Geranietum and Molinion vegetation surrounded by allotments, hedgerows and bushes (Bielany) or abandoned fields, intensively managed Calthion and Arrhenatherion meadows and Magnocaricion communities (Powsinek). At Bielany the meadows had formerly been partially and irregularly mown, or used as extensive pastures until 1998. At the time of this study the only treatments were irregular fires in the spring. Unfortunately later most of the $P$. teleius biotope was destroyed and developed. At Powsinek in some seasons the whole site was completely burnt in spring but probably without any negative effect on the population of $P$. teleius. After the studies, even this treatment ceased, and a few years later the site became almost completely overgrown, and then finally converted into a clover field. At Kosyń we studied a patch, which was quite heterogenous and consisted of a mosaic of Molinion and Salicetum pentandro-cinerae vegetation. The lowest parts were periodically very wet and covered by fen vegetation (Caricion fuscae). The fringes of the area were irregularly grazed. Phengaris nausithous (Bgstr.) was also pre- 
TABLE 1. Characteristics of the three Polish sites where the behaviour of females of $P$. teleius was studied.

\begin{tabular}{lccc}
\hline Study site & Powsinek & Bielany & Kosyń \\
\hline Area size & 0.5 ha & 2 ha & 0.5 ha \\
Estimated population size of adults & $300-500$ & $1000-2000$ & $300-500$ \\
Abundance of Sanguisorba officinalis & $2.2 / \mathrm{m}^{2}$ & $1.3 / \mathrm{m}^{2}$ & $0.5 / \mathrm{m}^{2}$ \\
Abundance of Myrmica ants & $1.29 / \mathrm{m}^{2}$ & $0.76 / \mathrm{m}^{2}$ & $0.83 / \mathrm{m}^{2}$ \\
$\quad$ M. rubra & $14 \%$ & $31 \%$ & $27 \%$ \\
M. scabrinodis & $81 \%$ & $29 \%$ & $7 \%$ \\
M. ruginodis & $5 \%$ & $40 \%$ & $66 \%$ \\
\hline gallienii & - & - & - \\
\hline
\end{tabular}

sent at this site and studies on its host-ant specificity suggested that it was about half as abundant there as P. teleius (Sielezniew $\&$ Stankiewicz, 2002). The site was about $800 \mathrm{~m}$ away and separated by bushes and hay meadows from other Phengaris populations.

The highest population density of $S$. officinalis plants was at Powsinek and the lowest at Kosyń. At Powsinek we recorded also a significantly higher density of Myrmica nests compared to the other two localities. Myrmica scabrinodis, M. rubra and $M$. ruginodis were present at the Warsaw localities while at Kosyń the latter species was replaced by M. gallienii. Percentages of nests of individual species of ants at each site varied greatly (Table 1).

\section{Recording of butterfly behaviour}

Observations were carried out at the peak of the flight period of $P$. teleius, i.e., between mid July and mid August 2000 and 2001, on sunny and not very windy days between 10 a.m. and 5 p.m. Individual females were tracked as long as possible, and the sequences of their activities were recorded with a digital video-camera, dictaphone and stopwatch. Accuracy of measurements was $1 \mathrm{~s}$. Data that was collected were later inserted into an Excel spreadsheet. We analysed only full activity, i.e., flight, nectaring (species of flower visited was noted) and egg laying. Resting, including basking, was not included in the analysis. For oviposition two events were distinguished. The first was rejection of a flower head, i.e., females landed on a flower head and flew off without laying an egg (or nectaring). The second included staying on flower heads, during which oviposition occurred. At the three sites we recorded a total number of 3022 events (1168 at Bielany, 1211 at Powsinek and 643 at Kosyń) lasting a total of $17 \mathrm{~h} 4 \mathrm{~min}(6 \mathrm{~h} 50 \mathrm{~min}, 6 \mathrm{~h} 22 \mathrm{~min}$ and $3 \mathrm{~h} 52$ min, respectively). Analyses of video material (i.e. wing pattern) indicated that we tracked at least 15 different females at Bielany, 20 at Powsinek and 10 at Kosyń.

We also collected flower heads for detailed examination. Four categories were distinguished: (1) flower heads collected just after an oviposition was observed and the female had flown off undisturbed, (2) flower heads initially accepted, but females were then disturbed and did not lay an egg, i.e., they were frightened off at the moment when they had apparently accepted a flower head and had inserted their ovipositor, (3) flower heads rejected by females and (4) flower heads chosen at random from those looking phenologically similar to those accepted by ovipositing females. On very rare occasions, when we observed more than one oviposition on a flower head we put those flower heads in separate bags. Until examination, the material was kept in a refrigerator to retard larval development. As soon as possible the flower heads were dissected in the laboratory and the number of eggs in each was counted. In the case of the first category, we estimated the number of eggs before oviposition, diminishing the number of eggs found by number of observed ovipositions, i.e., usually by one. For flower heads collected at Kosyń it was also necessary to distinguish eggs of $P$. teleius from the co-occurring $P$. nausithous. The eggs of the latter species were only rarely recorded probably due to the lower number of individuals and a preference of this species for ovipositing in older flower heads (Figurny \& Woyciechowski, 1998). Therefore, this data was not used as an additional variable in our analyses. Before dissection, we additionally measured the length of all the flower heads collected.

\section{Statistical analyses}

One-way ANOVA was used for comparisons of average durations of individual flights, nectaring and ovipositions/rejections recorded at the different sites, and t-tests were used to compare the average stay on flower heads of the two plant species. A logarithmic transformation was applied to the data to normalize distributions. The significance of differences in the number of eggs in S. officinalis flower heads, as well as flower head lengths among samples and sites was tested using nonparametric statistics, i.e., Kruskal-Wallis one-way ANOVA on ranks, or Mann-Whitney $U$ tests, to compensate for nonnormally distributed data. Moreover, we tested the significance of heterogeneity in the presence/absence of eggs or acceptance/rejection rates among sites/different groups using Fisher exact tests. When necessary we applied an extended version of this test, i.e., generalised to more than two compared samples as implemented at http://www.quantitativeskills.com/ sisa/. All other statistical analyses were made using STATISTICA. Mean values are given \pm SE.

\section{RESULTS}

\section{Flight}

Females were most mobile at Bielany where displacement flights accounted for about half of their activity, while at Powsinek and Kosyń this percentage was lower (Fig. 1). Average duration of individual flight ranged from $14.5 \mathrm{~s}$ at Kosyń to $19.5 \mathrm{~s}$ at Bielany (Table 2), and there was significant differentiation among sites (ANOVA: $F_{2,1496}=5.84, P=0.003$ ). Post-hoc Tukey test showed significant differences only between Bielany and Kosyń $(P=0.009)$, while two other pair wise comparisons were not significant (Bielany and Powsinek: $P=$ 0.118; Powsinek and Kosyń: $P=0.308)$. Regardless of the percentage of the time spent flying, females did not fly far but consistently explored restricted patches, searching for larval food plants. Even when they left a patch at the smaller sites (Powsinek and Kosyń) they always quickly returned. 


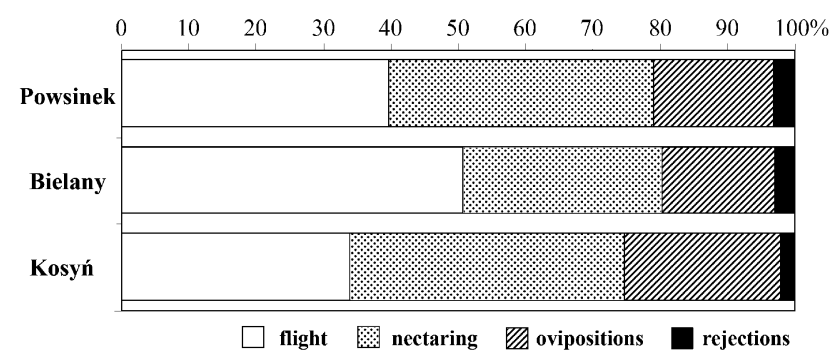

Fig. 1. Percentages of the total time active females of $P$. teleius spent flying, nectaring, ovipositing and rejecting flower heads at three sites in Poland.

\section{Nectaring}

At Powsinek and Kosyn the percentage of the time spent nectaring was very similar, while at Bielany it was lower (Fig. 1). Differences in average duration of an individual nectaring event among sites (Table 2 ) were not significant (ANOVA: $F_{2,500}=0.085, P=0.92$ ). S. officinalis and Viccia cracca L. were the main sources of nectar and females spent, respectively, 41.6 and $33.9 \%$ of total time nectaring at Bielany, 21.6 and $72.4 \%$ at Powsinek and 52.3 and $46.8 \%$ at Kosyń feeding from flowers of these species. There were no significant differences between different sites for each nectar plant and analysis of the pooled sample showed that mean individual nectaring on $V$. cracca $(59.0 \pm 5.3 \mathrm{~s})$ was significantly longer than on $S$. officinalis $(31.1 \pm 2.8 \mathrm{~s})\left(t_{454}=-6.01, P<0.0001\right)$. Of other plants, only Serratula tinctoria L. was frequently used at Bielany $(22.8 \%)$, but this species was absent at the other localities. Other plants, i.e., Lythrum salicaria L., Cirsium arvense (L.) Scop., C. palustrae (L.) Scop., Centaurea jacea L., Allium angulosum L., Veronica longifolia L., Betonica officinalis L. and Trifolium pratense L. were visited rather sporadically. All nectar flowers were coloured in shades of purple, pink or red. We never observed feeding at a yellow flower although, e.g., Lathyrus pratensis L. often occurred with $V$. cracca plants and was frequently visited by other lycaenids.

\section{Oviposition behaviour}

The percentage of the time active spent in behaviour related to oviposition ranged from $19.7 \%$ at Bielany to $25.3 \%$ at Kosyń (Fig. 1). Mean duration of a visit to a flower head that resulted in egg laying was very similar at all sites, and ranged from $33 \mathrm{~s}$ at Powsinek and Kosyń to $35 \mathrm{~s}$ at Bielany (Table 2) (ANOVA: $F_{2,291}=0.81, P=$ 0.44). Three phases were distinguished: (1) pre-

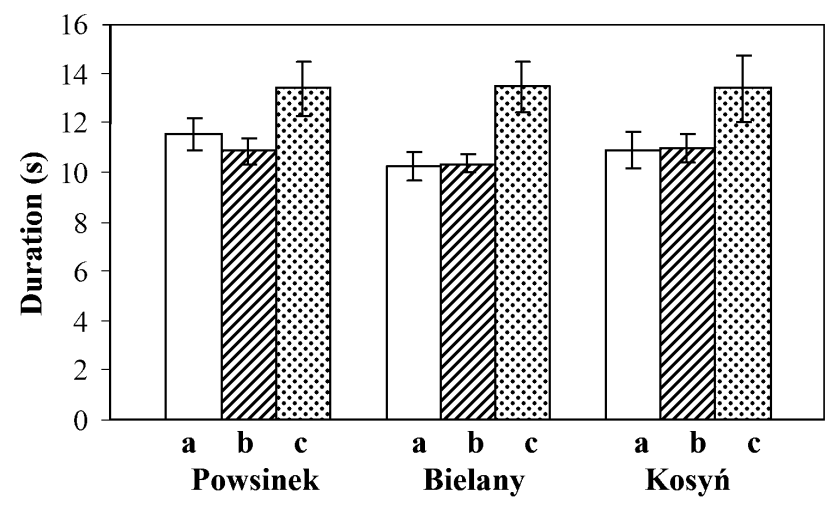

Fig. 2. The mean duration in seconds $( \pm \mathrm{SE}$ ) of the three phases in oviposition behaviour of $P$. teleius at three localities in Poland: a - pre-oviposition, b - ovipositing, c - postoviposition.

oviposition, i.e., period from landing on a flower head to insertion of ovipositor; (2) actual oviposition, i.e., when the ovipositor of a nearly motionless female remained hidden within a flower head; (3) post-oviposition stay on a flower head, i.e., period from removal of ovipositor to departure from the flower head.

In the first phase, a female investigated a flower head with her forelegs, proboscis and often also the tip of the abdomen. In the final phase a female performed a kind of specific dance, walking around a flower head, drumming with forelegs and often opening its wings. Duration of all three phases was very variable, but average figures were similar at the three sites (Fig. 2). Mean rate of oviposition when fully active was 15.1 eggs per hour at Bielany, 22.5 at Kosyń and 26.5 at Powsinek.

The other main type of oviposition behaviour was related to rejection of inappropriate flower heads. Usually (61-66\% of cases) it occurred very quickly not taking longer than one second, but in the remaining cases it could be as long as half a minute. Differences in mean duration of rejections between sites (range: 2.2-2.6 s) (Table 2) were not significant (ANOVA: $F_{2,723}=1.22, P$ $=0.30$ ). At all sites studied rejections prevailed over acceptances, but this relation was variable (Fisher's exact test: $P<0.0001$ ). The highest rejection/oviposition rate (4.9) was recorded at Bielany, where it was significantly higher than at both Kosyń $(2.5)(P=0.0001)$ and Powsinek (1.7) $(P<0.0001)$, and the difference between the two latter sites was also significant $(P=0.007)$.

TABLE 2. Mean duration (in seconds) of four basic activities of females of P. teleius recorded while tracking them at three sites in Poland.

\begin{tabular}{|c|c|c|c|c|c|c|c|c|c|c|c|c|}
\hline \multirow[t]{2}{*}{ Site } & \multicolumn{3}{|c|}{ Flight } & \multicolumn{3}{|c|}{ Nectaring } & \multicolumn{3}{|c|}{ Ovipositions } & \multicolumn{3}{|c|}{ Rejections } \\
\hline & $\mathrm{N}$ & Mean & SE & $\mathrm{N}$ & Mean & SE & $\mathrm{N}$ & Mean & SE & $\mathrm{N}$ & Mean & $\mathrm{SE}$ \\
\hline Powsinek & 576 & 16.9 & 0.9 & 230 & 42.2 & 3.2 & 114 & 33.1 & 1.2 & 291 & 2.59 & 0.28 \\
\hline Bielany & 596 & 19.5 & 1.0 & 169 & 39.9 & 3.5 & 102 & 35.0 & 1.3 & 301 & 2.21 & 0.21 \\
\hline Kosyń & 327 & 14.4 & 1.0 & 104 & 54.7 & 9.7 & 78 & 32.8 & 1.5 & 134 & 2.19 & 0.30 \\
\hline Total & 1499 & 17.4 & 0.6 & 503 & 44.0 & 2.7 & 294 & 33.7 & 0.8 & 726 & 2.36 & 0.15 \\
\hline
\end{tabular}




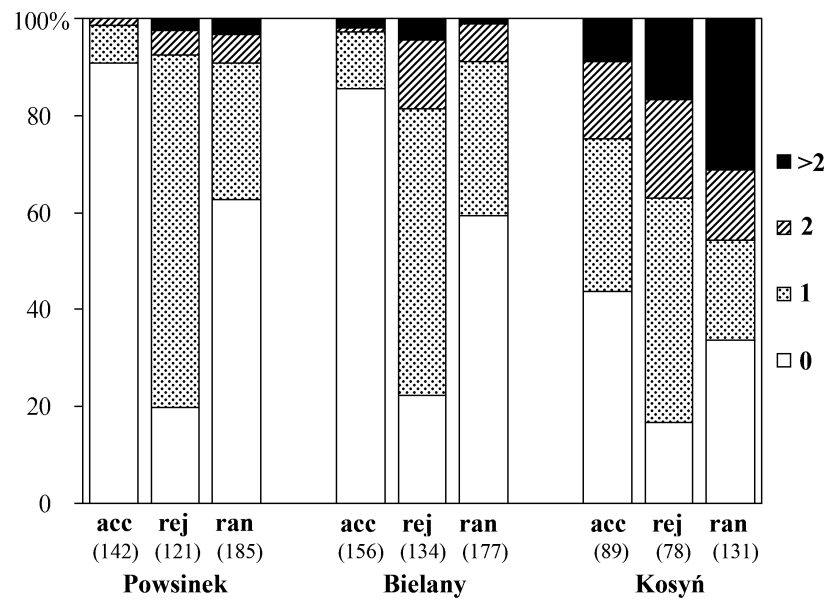

Fig. 3. Percentage frequency of $0,1,2$ and $>2$ eggs in the three groups of flower heads collected at three P. teleius sites in Poland: acc - accepted (before oviposition), rej - rejected by females, ran - randomly sampled flower heads; sample sizes for each group are given in parenthesis.

\section{Presence of eggs in Sanguisorba flower heads}

We did not find significant differences either in the median number of eggs (Powsinek: $U=2435.0, N_{l}=62$, $N_{2}=79, P=0.91$; Bielany: $U=2386.5, N_{1}=92, N_{2}=53$, $P=0.72$; Kosyń: $\left.U=852.5, N_{1}=30, N_{2}=60, P=0.66\right)$ or in flower head length $(U=2333.5, P=0.54 ; U=$ 2119.5, $P=0.18 ; U=856.5, P=0.71$; respectively) between flower heads collected just after observed oviposition and flower heads initially accepted (see the previous chapter). When we analysed presence/absence of eggs in dissected flower heads there were also no significant differences (Fisher's exact test: $P=0.15-0.22$ ). Therefore, in all further comparisons they were lumped together in a single group called "accepted".

Most of the accepted flower heads collected at Powsinek and Bielany contained no eggs prior to an oviposition event. In the case of Kosyń, less than half of the flower heads were without eggs. In contrast, among the rejected flower heads this percentage was different and lower. However, for randomly sampled flower heads the corresponding percentage was intermediate (Fig. 3). The maximum number of eggs ranged from 2 for accepted flower heads collected at Powsinek to 8 for flower heads sampled at random at Kosyń. Median numbers of eggs were 0 (accepted and randomly sampled at Powsinek and Bielany) or 1 (all other cases) (Fig. 4a).

There was significant heterogeneity in presence/ absence of eggs among the three categories of flower heads collected at all three sites i.e.: Powsinek (Fisher's exact test: $P<0.0001)$, Bielany $(P<0.0001)$ and Kosyń $(P=0.0006)$. Pair wise comparisons showed significant differences for all groups at Powsinek and Bielany $(P<$ $0.0001)$. At Kosyń differences in frequency were significant between accepted and rejected $(P=0.002)$ and between rejected and randomly sampled $(P=0.010)$, but not between accepted and randomly sampled flower heads $(P=0.12)$. However, when we additionally divided flower heads into four categories (containing $0,1,2, \geq 3$ eggs), a heterogeneity for the latter comparison was also significant $(P=0.0007)$.

There was a significant difference in median number of eggs among accepted, rejected and randomly sampled flower heads for all sites, i.e. Powsinek (Kruskal-Wallis test: $\left.H_{2}=127.1, N=446, P<0.0001\right)$, Bielany $\left(H_{2}=\right.$ 114.5, $N=456, P<0.0001)$ and Kosyń $\left(H_{2}=9.92, N=\right.$ $288, P=0.007)$. For Powsinek and Bielany all pair wise comparisons were significant $(P<0.0001)$, i.e., median number of eggs in accepted flower heads was lower than in rejected and randomly sampled flower heads, and there were more eggs in rejected flower heads than in those sampled at random. For Kosyń, the median number of eggs was lower for accepted than for rejected flower heads $(P=0.010)$. However, significant differences were not detected either between those randomly sampled and accepted $(P=0.10)$ or between those randomly sampled and rejected $(P=0.81)$.
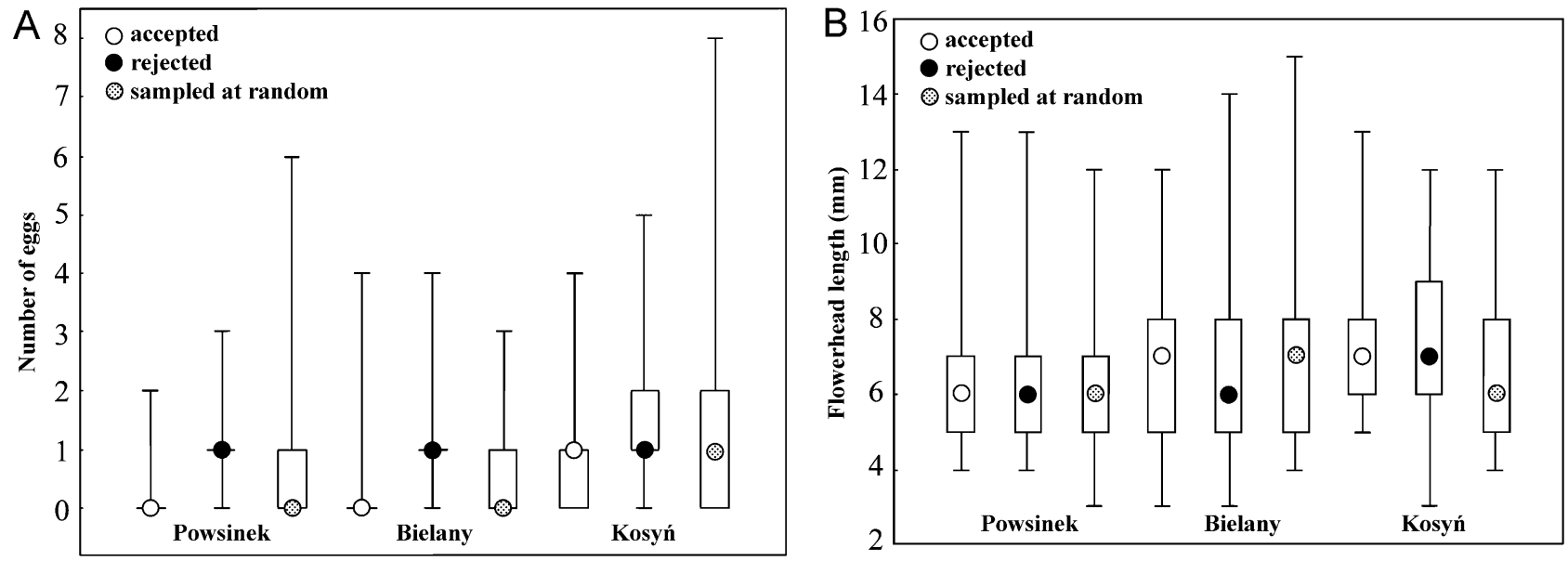

Fig. 4. Features of the Sanguisorba officinalis flower heads that were accepted/rejected by females of $P$. teleius and those randomly sampled during this study at three sites in Poland. The box and whisker plots show the median, first and third quartiles and the minimum and maximum values for (a) number of $P$. teleius eggs found and (b) flower head length. 
Lengths of flower heads ranged from 3 to $15 \mathrm{~mm}$ and median values were 6-7 mm (Fig. 4b). Accepted, rejected and randomly sampled flower heads did not differ significantly in their length in the case of Kosyń $\left(\mathrm{H}_{2}=5.12, \mathrm{~N}\right.$ $=288, P=0.077)$. For Powsinek there was a significant difference $\left(\mathrm{H}_{2}=7.47, \mathrm{~N}=446, P=0.024\right)$, but pair wise comparisons were not significant $(P=0.052-1.000)$. However, for Bielany differences among categories of flower heads were significant $\left(H_{2}=9.19, N=456, P=\right.$ $0.010)$ and pair wise comparisons showed that accepted flower heads were longer than rejected $(P=0.025)$ and randomly sampled ones $(P=0.031)$, and there were no significant differences between the latter two categories $(P=1.00)$.

\section{DISCUSSION}

When fully active, the tracked females switched between nectaring, flight and oviposition. Their behaviour was probably affected both by the size of the patch of habitat and abundance of larval food plants. At the relatively large site at Bielany, females spent more time flying than at the smaller sites at Powsinek and Kosyń. It is plausible that the lower abundance of $S$. officinalis at Bielany forced females to spend more time searching for appropriate resources. In contrast, at Powsinek an abundance of both larval food and nectar plants meant they did not have to spend much time flying between plants. Tracked females tended to remain in their breeding habitats, although $S$. officinalis was present locally in surrounding meadows. Therefore our observations are consistent with data on the population ecology of $P$. teleius, which indicates that this butterfly is not a highly mobile species (Nowicki et al., 2005b).

Nectaring females of $P$. teleius show a striking preference for flowers of certain colours. In the present study they were recorded exclusively on reddish or pinkish flowers and never on white or yellow. The partiality for feeding on $V$. cracca, which was also frequently visited and locally even favoured over $S$. officinalis, seems to be typical of P. teleius (Thomas, 1984). Preferences for certain colours are often recorded for butterflies (e.g. Kevan \& Baker, 1983). P. nausithous, which is the closest relative of $P$. teleius, is even more specific and very rarely visits flowers other than those of $S$. officinalis (Thomas, 1984; Pfeifer et al., 2000; Wynhoff, 2001). However, females of $P$. nausithous oviposit on older flower heads and often switched between nectaring and oviposition during a single stay on a flower head. The congeneric xerothermophilus $P$. arion (L.). prefers the food plants of its larvae, i.e. Thymus L. and Origanum vulgare L., but like $P$. teleius may also be observed on other pink flowers, especially Viccia L. In contrast, Phengaris alcon (Den et Schiff.), which sometimes occurs sympatrically with $P$. teleius in humid ecotypes, frequently also visits yellow flowers (Ebert \& Rennwald, 1991).

The mean rate of egg laying when fully active recorded in this study is very similar to that estimated by Van Dyck \& Regniers (2010) for P. alcon (ca. 19 eggs/h). However, the oviposition behaviour of $P$. teleius seems to be dif- ferent as the qualitative (presence/absence) and/or quantitative (number of eggs) data on eggs indicate that females of $P$. teleius avoid laying eggs in flower heads previously visited by congeneric females. It is likely that the females mark flower heads in which they have oviposited with a pheromone, which deters other females from laying eggs. This was very obvious at Powsinek and Bielany, where most of the accepted flower heads were free of eggs and rejected flower heads had eggs from a previous oviposition. At Kosyń, the differences were less clear but also significant. However, quantitative analyses confirmed this pattern occurred at all three sites.

That females might leave chemical marks on flower heads was also indicated by their behaviour. Oviposition visits to flower heads were highly stereotyped and followed a specific ritual. A female examined a flower head with its antennae, legs and sometimes also with the tip of its abdomen. Physical contact with the surface triggered a specific drumming using the forelegs, as observed in Pieris brassicae testing cabbage leaves (Thompson \& Pellmyr, 1991). In the case of $P$. teleius, females stayed for some time on flower heads after oviposition during which they performed a dance and touched the flower head with its antennae or the tip of its abdomen. In contrast, rejection was usually a very quick process. It is possible that this quick rejection of flower heads is the result of the females detecting pheromones using the chemoreceptors on their tarsi and abdomen, as recorded for $P$. brassicae (Klijnstra \& Roessingh, 1986), and in the cases when the examination is even more prolonged other cues were probably important, e.g. the flowers were too small (making oviposition difficult) or they were not in the right physiological state of development. However it is unclear whether this hypothetical pheromone accompanies an egg or is deposited directly. It is unlikely that visual cues are involved, as reported for some other butterflies (Schoonhoven, 1990), since $P$. teleius eggs are hidden in flower heads and therefore virtually impossible to find quickly.

To our knowledge this is the first evidence of a putative ODP in the Lycaenidae. It is not excluded that this kind of signalling is more common, especially among species whose caterpillars feed upon inflorescences. This ODP may reduce larval competition by enabling females to choose flower heads in which their larvae are most likely to survive (Nufio \& Papaj, 2001). For example, it is also suspected that females of Cupido minimus (Fuessly) deposit scent on buds of Anthyllis vulneraria L. to deter other females from ovipositing. However, this effect is probably short-lived, i.e., it lasts for 1-2 days (Thomas \& Lewington, 2010). On the other hand the ODPs of Pieris butterflies are chemically very stable. However watersoluble chemical marks may be easily washed off by rain and therefore less effective in wet seasons (Schoonhoven, 1990).

Data from Kosyń, where females often oviposited in flower heads already bearing conspecific eggs, but where the distribution of offspring tended to be rather uniform, also suggest that the hypothetical pheromone is not very persistent, or females are able to determine the amount 
and react appropriately to local conditions, which are determined by the availability of flower heads without eggs. Rare cases of repeated ovipositions in the same flower heads may be consequence of a scarcity of the larval food plant. In contrast, the highest rejection rate was recorded at Bielany, i.e., at a large site where there was a moderate density of $S$. officinalis plants and low density of Myrmica nests, and thus possibly fewer adult butterflies and therefore less competition between larvae. Adult butterflies are capable of learning, which enables them to optimize their use of nectar resources (McNeely \& Singer, 2001; Weiss \& Papaj, 2003). The role of learning in oviposition is generally less appreciated (García-Barros \& Fartmann, 2009), but is known to have a role in the host selection behaviour in several butterflies (Papaj \& Rausher, 1987; Goulson \& Cory, 1993; Goulson et al., 1997). There are also data on another insect, the maggot fly, which indicates that the response to ODP is dependent on previous experience (Roitberg \& Prokopy, 1981). Moreover females of some species of butterfly, which lay clusters of eggs, can adjust the number of eggs laid on a host plant depending on their visual response to its size and/or the presence of conspecific eggs/larvae (Rothschild \& Schoonhoven, 1977; Pilson \& Rausher, 1988; Vasconcellos-Neto \& Monteiro, 1993). Therefore it is not out of the question that females of $P$. teleius are flexible in their oviposition decisions depending on the availability of local or seasonal resources. In the future it would be also interesting to determine whether their oviposition behaviour differs depending whether it is the beginning or the end of the flight period and the ages of the females.

Our findings are inconsistent with those of Figurny \& Woyciechowski (1998), who claim that previously laid eggs are not recognized. However their evaluation of $P$. teleius ovipositing behaviour was based on relatively little evidence. It is also likely that Figurny \& Woyciechowski (1998) classified some rejected flower heads as accepted, as they assumed that every abdominal bend and touching of the surface of the flower head with the abdominal tip was associated with egg laying. Our studies show that successful oviposition is associated with a specific ritual and lasted considerably longer than rejection.

There are some hints that indicate it is more important for $P$. teleius than for its congeners to be able to recognize the presence of conspecific eggs. Firstly, it is likely that caterpillars of $P$. teleius have to compete more strongly during the endophytic stage of life, as they are relatively large. At the beginning of the fourth instar, i.e., when they leave the food plant, their mean body biomass is over $4 \mathrm{mg}$, i.e., about 3-4 times more than the larvae of $P$. nausithous, which also exploit $S$. officinalis flower heads (Thomas, 1984), and caterpillars of $P$. arion and $P$. alcon are also smaller (Thomas \& Wardlaw, 1992; Sielezniew \& Stankiewicz, 2007).

Further studies are needed to assess whether $P$. teleius is exceptional among Phengaris butterflies. Its close relative $P$. nausithous does not recognize either conspecific or congeneric eggs (Figurny \& Woyciechowski, 1998).
The presence of eggs definitely does not deter females of Phengaris alcon from ovipositing as plants may bear many eggs (Van Dyck \& Regniers, 2010). However, it is important to note that in this case the larval food plants, i.e., Gentiana spp., are distributed patchily in the habitats frequented by the butterfly and are usually less abundant than Sanguisorba. Therefore, females of $P$. alcon usually simply have no choice and as a consequence oviposit on plants with conspecific eggs. Then, in the case of $P$. arion, flower heads are usually very abundant and very close to each other. Oviposition-related visits to flower heads of Thymus spp. are also relatively short and behaviour does not suggest marking (own observations). However, in Italy where there is an alternative larval food plant (Origanum vulgare) females spend more time evaluating oviposition sites on plants within the foraging territory of their Myrmica hosts (Patricelli et al., 2011).

There is an ongoing discussion as to whether oviposition of obligatorily myrmecophilous Phengaris butterflies may be to some extent related to the close presence of their host ants. Ant-mediated oviposition is recorded for some lycaenids and riodinids (e.g. DeVries \& Penz, 2000; Pierce et al., 2002). However, all this data is for tropical species. In Europe, some data suggests that it may happen in Plebejus argus (L.) (Jordano et al., 1992). There are contradictory data about Phengaris (Maculinea) butterflies. Some authors are of the opinion that the phenological state of the larval food plant and microhabitat conditions are the most important cues (Thomas \& Elmes, 2001; Nowicki et al., 2005a; Musche et al., 2006; Fürst \& Nash, 2010) but other studies suggest ant-mediated oviposition (Van Dyck et al., 2000; Wynhoff et al., 2008; Van Dyck \& Regniers, 2010; Patricelli et al., 2011).

According to Wynhoff et al. (2008), females of $P$. teleius more often deposit eggs on plants near M. scabrinodis ants, i.e. this species used to be considered as a specific host of the butterfly (Thomas et al., 1989). P. teleius shows little host-ant specificity in Poland, including in the areas of the present study (Stankiewicz \& Sielezniew, 2002; Witek et al., 2008, 2010). Moreover at most of the sites the numbers of nests of potential hosts is relatively high (Stankiewicz \& Sielezniew, 2002 and unpubl. data). Therefore virtually all plants are in the foraging zone of Myrmica workers, i.e. within a radius of $2 \mathrm{~m}$ of a colony (Elmes et al., 1998). In these circumstances, a female's ability to find Myrmica nests is likely to be less important. Moreover, even when a fourth instar larva of $P$. teleius is discovered by a worker, the chances for it successfully completing its development are relatively low, as not all nests of potential hosts are equally likely to be infested with butterfly larvae (Thomas et al., 2005). On the other hand, when many predatory caterpillars are adopted by benign colonies, they experience scramble competition (Thomas \& Elmes, 1998). Therefore, random and even distribution of eggs seems to be an optimal way of increasing the overall survival rate of caterpillars during both the phytophagous and parasitic stages of their development. One may expect that this strategy is also beneficial also for other predatory Phengaris species. 
In summary, the results presented here indicate that intra-specific signalling is the key factor determining where $P$. teleius females lay an egg after a preliminary visual assessment of potential suitability. Further studies are necessary to establish the properties of the hypothetical marking pheromone, i.e. its chemistry, persistence and volatility, and where it is synthesized, how it is applied and detected. It would be also interesting to determine the ability of females to learn and whether ODPs are more widespread among lycaenids.

ACKNOWLEDGEMENTS. We wish to thank K. Sambor for help with field studies in Warsaw. M. Sielezniew was supported by a grant from the Warsaw University of Life Sciences (SGGW) (504 042 80012). I. Wynhoff, J. Settele and an anonymous reviewer made many valuable comments and suggestions for improving the manuscript.

\section{REFERENCES}

ANDERson P. 2002: Oviposition pheromones in herbivorous and carnivorous insects. Hilker M. \& Meiners T. (eds): Chemoecology of Insect Eggs and Egg Deposition. Blackwell, Oxford, pp. 235-264.

Árnyas E., Bereczki J., Tóth A., Varga K., Pecsenye K., Tartally A., Kövics G., Karsa D. \& Varga Z. 2009: Oviposition preferences of Maculinea alcon as influenced by aphid (Aphis gentianae) and fungal (Puccinia gentianae) infestation of larval host plants. - Ecol. Entomol. 34: 90-97.

Buszko J., Sielezniew M. \& Stankiewicz A.M. 2005: The distribution and ecology of Maculinea teleius and M. nausithous in Poland. In Settele J., Kühn E. \& Thomas J.A. (eds): Studies on the Ecology and Conservation of Butterflies in Europe. Vol. 2: Species Ecology along a European Gradient: Maculinea Butterflies as a Model. Pensoft, Sofia, Moscow, pp. 210-213.

DEMPSTER J.P. 1992: Evidence of an oviposition-deterring pheromone in the orange-tip butterfly, Anthocharis cardamines (L.). - Ecol. Entomol. 17: 83-85.

DeVries P.J. \& Penz C.M. 2000: Entomophagy, behavior, and elongated thoracic legs in the myrmecophilous neotropical butterfly Alesa amesis (Riodinidae). - Biotropica 32: 712-721.

Ebert G. \& Rennwald E. 1991: Die Schmetterlinge BadenWürttembergs, Vol. 1 \& 2, Tagfalter I \& II. Eugen Ulmer, Stuttgart, $552+535 \mathrm{pp}$.

Elmes G.W. \& Thomas J.A. 1992: Complexity of species conservation in managed habitats: Interactions between $\mathrm{Macu}$ linea butterflies and their ant hosts. - Biodiv. Conserv. 1: $155-169$.

Elmes G.W., Thomas J.A., Wardlaw J.C., Hochberg M.E., Clarke R.T. \& Simcox D.J. 1998: The ecology of Myrmica ants in relation to the conservation of Maculinea butterflies. - J. Insect Conserv. 2: 67-78.

FIgURNY E. \& WoyciechowsKi M. 1998: Flowerhead selection for oviposition by females of the sympatric butterfly species Maculinea nausithous and M. teleius (Lepidoptera, Lycaenidae). - Entomol. Gen. 23: 215-222.

Fric Z., Wahlberg N., Pech P. \& ZrZavý J. 2007: Phylogeny and classification of the Phengaris-Maculinea clade (Lepidoptera: Lycaenidae): total evidence and phylogenetic species concepts. - Syst. Entomol. 32: 558-567.

FÜrST M.A. \& NASH D.R. 2009: Host ant independent oviposition in the parasitic butterfly Maculinea alcon. - Biol. Lett. 6: $174-176$.
García-Barros E. \& Fartmann T. 2009: Butterfly oviposition: sites, behaviour and modes. In Settele J., Shreeve T.G., Konvicka M. \& Van Dyck H. (eds): Ecology of Butterflies in Europe. Cambridge University Press, Cambridge, pp. 29-42.

Goulson D. \& CORY J.S. 1993: Flower constancy and learning in foraging preferences of the green-veined white butterfly Pieris napi. - Ecol. Entomol. 18: 315-320.

Goulson D., Ollerton J. \& Sluman C. 1997: Foraging strategies in the small skipper butterfly, Thymelicus flavus; when to switch? - Anim. Behav. 53: 1009-1016.

JAENIKE J. 1990: Host specialization in phytophagous insects. Annu. Rev. Ecol. Syst. 21: 243-273.

Jordano D., Rodriguez J., Thomas C.D. \& Haeger J.F. 1992: The distribution and density of a lycaenid butterfly in relation to Lasius ants. - Oecologia 91: 439-446.

KeVAn P.G. \& BAKer H.G. 1983: Insects as flower visitors and pollinators. - Annu. Rev. Entomol. 28: 407-453.

Klijnstra J.W. \& Roessingh P. 1986: Perception of the oviposition deterring pheromone by tarsal and abdominal contact chemoreceptors in Pieris brassicae. - Entomol. Exp. Appl. 40: 71-79.

McNeely C. \& Singer M.C. 2001: Contrasting the roles of learning in butterflies foraging for nectar and oviposition sites two. - Anim. Behav. 65: 847-852.

Munguira M.L., García-Barros E. \& Cano J.M. 2009: Butterfly herbivory and larval ecology. In Settele J., Shreeve T.G., Konvicka M. \& Van Dyck H. (eds): Ecology of Butterflies in Europe. Cambridge University Press, Cambridge, pp. 43-54.

Musche M., Anton C., Worgan A. \& Settele J. 2006: No experimental evidence for host ant related oviposition in a parasitic butterfly. - J. Insect Behav. 19: 631-643.

Nowicki P., Witek M., Skórka P. \& Woyciechowski M. 2005a: Oviposition patterns in the myrmecophilous butterfly $\mathrm{Macu}$ linea alcon Denis \& Schiffermüller (Lepidoptera: Lycaenidae) in relation to characteristics of foodplants and presence of ant hosts. - Pol. J. Ecol. 53: 105-111.

Nowicki P., Witek M., Skórka P., Settele J. \& Woyciechowski M. 2005b: Population ecology of the endangered butterflies Maculinea teleius and M. nausithous, and its implications for conservation. Popul. Ecol. - 47: 409-417.

Nufio C.R. \& PAPAJ D.R. 2001: Host marking behavior in phytophagous insects and parasitoids. - Entomol. Exp. Appl. 99: 273-293.

PAPAJ D.R. \& RAusher M.D. 1987: Genetic differences and phenotype plasticity as causes of variation in oviposition preference in Battus philenor. - Oecologia 74: 24-30.

Patricelli D., Barbero F., La Morgia V., Casacci L.P., Witek M., Balletto E. \& Bonelli S. 2011: To lay or not to lay: oviposition of Maculinea arion in relation to Myrmica ant presence and host plant phenology. - Anim. Behav. 82: 791-799.

Pfeifer M.A., Andrick U.R., Frey W. \& Settele J. 2000: On the ethology and ecology of a small and isolated population of the Dusky Large Blue Butterfly Glaucopsyche (Maculinea) nausithous (Bergsträsser, 1779) (Lep., Lycaenidae). — Nota Lep. 23: 147-172.

Pierce N.E. \& Elgar M.A. 1985: The influence of ants on host plant selection by Jalmenus evagoras, a myrmecophilous lycaenid butterfly. - Behav. Ecol. Sociobiol. 16: 202-222.

Pierce N.E., Braby M.F., Heath A., Lohman D.J., Mathew J., Rand D.B. \& Travassos M.A. 2002: The ecology and evolution of ant association in the Lycaenidae (Lepidoptera). Annu. Rev. Entomol. 47: 733-771.

Pilson D. \& Rausher M.D. 1988: Clutch size adjustment by a swallowtail butterfly. - Nature 333: 361-363. 
PORTER K. 1982: Basking behaviour in larvae of the butterfly Euphydryas aurinia. - Oikos 38: 308-312.

Renwick J.A.A. \& Chew F.S. 1994: Oviposition behavior in Lepidoptera. - Annu. Rev. Entomol. 39: 377-400.

RoItBerg B.D. \& PROKopy R.J. 1981: Experience required for pheromone recognition by the apple maggot fly. - Nature 292: $540-541$.

Roitberg B.D. \& Prokopy R.J. 1987: Insects that mark host plants. - BioScience 37: 400-406.

Sato Y., Yano S., Takabayashi J. \& Ohsaki N. 1999: Pieris rapae (Lepidoptera: Pieridae) females avoid oviposition on Rorippa indica plants infested by conspecific larvae. - Appl. Entomol. Zool. 34: 333-337.

Schoonhoven L.M. 1990: Host-marking pheromones in Lepidoptera, with special reference to two Pieris spp. - J. Chem Ecol. 16: 3043-3052.

Schoonhoven L.M. \& Rothschild M. 1977: Assessment of egg load by Pieris brassicae (Lepidoptera: Pieridae). - Nature 266: 352-355.

Schoonhoven L.M., Beerling E.A.M., Braaksma R. \& van Vugt Y. 1990a: Does the imported cabbageworm, Pieris rapae, use an oviposition deterring pheromone? - J. Chem. Ecol. 16: 1649-1655.

Schoonhoven L.M., Beerling E.A.M., Klinnstra J.W. \& van VugT Y. 1990b: Two related butterfly species avoid oviposition near each other's eggs. - Experienta 46: 526-528.

Settele J., Kühn E. \& Thomas J.A. (eds) 2005: Studies on the Ecology and Conservation of Butterflies in Europe. Vol. 2: Species Ecology along a European Gradient: Maculinea Butterflies as a Model. Pensoft, Sofia, Moscow, $250 \mathrm{pp}$.

Sielezniew M. \& Stankiewicz A.M. 2007: Differences in the development of the closely related myrmecophilous butterflies Maculinea alcon and $M$. rebeli (Lepidoptera: Lycaenidae). - Eur. J. Entomol. 104: 433-444.

Stankiewicz A. \& SielezNiew M. 2002: Host specificity of Maculinea teleius Bgstr. and M. nausithous Bgstr. (Lepidoptera: Lycaenidae). The new insight. - Ann. Zool. 52: 403-408.

Stanton M.L. 1984: Short-term learning and the searching accuracy of egg laying butterflies. - Anim. Behav. 32: $33-40$.

Stettmer C., Binzenhöfer B. \& Hartmann P. 2001: Habitatmanagement und Schutzmaßnahmen für die Ameisenbläulinge Glaucopsyche teleius und Glaucopsyche nausithous, Teil 2: Habitatansprüche, Gefährdung und Pflege. Nat. Landsch. - 76: 366-375

TARTAlly A. \& VARga Z. 2008: Host ant use of Maculinea teleius in the Carpathian Basin (Lepidoptera: Lycaenidae). Acta Zool. Acad. Sci. Hung. 54: 257-268.

Thоmas J.A. 1984: The behaviour and habitat requirements of Maculinea nausithous (the Dusky Large Blue Butterfly) and M. teleius (the Scarce Large Blue) in France. - Biol. Conserv. 28: 325-347.

Thomas J.A. 1995: The ecology and conservation of Maculinea arion and other European species of large blue butterfly. In Pullin A.S. (ed.): Ecology and Conservation of Butterflies. Chapman and Hall, pp. 180-197.

Thomas J.A. \& Elmes G.W. 1998: Higher productivity at the cost of increased host-specificity when Maculinea butterfly larvae exploit ant colonies through trophallaxis rather than by predation. - Ecol. Entomol. 23: 457-464.

Thomas J.A. \& Elmes G.W. 2001: Food-plant niche selection rather than the presence of ant nests explains oviposition patterns in the myrmecophilous butterfly genus Maculinea. Proc. R. Soc. Lond. (B) 268: 471-477.
Thomas J.A. \& Lewington R. 2010: The Butterflies of Great Britain \& Ireland. British Wildlife Publishing, Milton on Stour, $288 \mathrm{pp}$

Thomas J.A. \& Settele J. 2004: Butterfly mimics of ants. Nature 432: 283-284.

ThOMAs J.A. \& WardLAW J.C. 1992: The capacity of a Myrmica ant nest to support a predacious species of Maculinea butterfly. - Oecologia 91: 101-109.

Thomas J.A., Elmes G.W., Wardlaw J.C. \& Woyciechowski M. 1989: Host specificity among Maculinea butterflies in Myrmica ant nests. - Oecologia 79: 452-457.

Thomas J.A., Elmes G.W., Schönrogge K., Simcox D.J. \& SetTELE J. 2005: Primary hosts, secondary hosts and "non-hosts": common confusions in the interpretation of host specificity in Maculinea butterflies and other social parasites of ants. In Settele J., Kühn E. \& Thomas J.A. (eds): Studies on the Ecology and Conservation of Butterflies in Europe. Vol. 2: Species Ecology along a European Gradient: Maculinea Butterflies as a Model. Pensoft, Sofia, Moscow, pp. 99-104.

Thompson J.N. \& Pellmyr O. 1991: Evolution of oviposition behavior and host preference in Lepidoptera. - Annu. Rev. Entomol. 36: 65-89.

Tolman T. \& Lewington R. 2009: Collins Butterfly Guide of Britain and Europe. Harper Collins, London, 400 pp.

VAN DyCK H. \& REgNIERS S. 2010: Egg spreading in the antparasitic butterfly, Maculinea alcon: from individual behaviour to egg distribution pattern. - Anim. Behav. 80: 621-627.

Van Dyck H., Talloen W., Oostermeijer J.G.B., Feenstra V., VAn der Hidde A. \& Wynhoff I. 2000: Does the presence of ant nests matter for oviposition to a specialized myrmecophilous Maculinea butterfly? - Proc. R. Soc. Lond. (B) 267: 861-866.

VAn LANGEVelde F. \& WynhofF I. 2009: What limits the spread of two congeneric butterfly species after their reintroduction: quality or spatial arrangement of habitat? - Anim. Conserv. 12: $540-548$.

Van SwaAy C.A.M. \& Warren M.S. 1999: Red Data Book of European Butterflies (Rhopalocera). Nature and Environment, No. 99. Council of Europe Publishing, Strasbourg, 260 pp.

Vasconcellos-Neto J. \& Monteiro R.F. 1993: Inspection and evaluation of host-plant by the butterfly Mechanitis lysimnia (Nymph., Ithomiinae) before laying eggs: a mechanism to reduce intraspecific competition. - Oecologia 95: 431-438.

WeISS M.R. \& PAPAJ D.R. 2003: Colour learning in two behavioral contexts: How much can a butterfly keep in mind? Anim. Behav. 65: 425-434.

WIKLUND C. 1984: Egg-laying patterns in butterflies in relation to their phenology and the visual apparency and abundance of their host-plants. - Oecologia 63: 23-29.

Witek M., Nowicki P., Śliwińska E.B., Skórka P., Moroń D., Settele J., Schonrogge K. \& Woyciechowski M. 2010: Local host ant specificity of Maculinea teleius butterfly, a obligatory social parasite of Myrmica ants. - Ecol. Entomol. 35: 557-564.

Witek M., Śliwińska E., Skórka P., Nowicki P., Settele J. \& Woyciechowski M. 2006: Polymorphic growth in larvae of Maculinea butterflies, as an example of biennialism in myrmecophilous insects. - Oecologia 148: 729-733.

Witek M., Śliwińska E.B., Skórka P., Nowicki P., Wantuch M., Vrabec V., Settele J. \& Woyciechowski M. 2008: Host ant specificity of Large Blue butterflies Phengaris (Maculinea) (Lepidoptera: Lycaenidae) inhabiting humid grasslands in East-central Europe. - Eur. J. Entomol. 105: 871-877.

Wynhoff I. 1996: Maculinea teleius (Bergstr., 1779). In Van Helsdingen P.J., Willemse L. \& Speight M.C.D. (eds): Back- 
ground Information on Invertebrates of the Habitats Directive and the Bern Convention. Part I - Crustacea, Coleoptera and Lepidoptera. Nature and Environment No 79. Council of Europe Publishing, Strasbourg, pp. 172-179.

Wynhoff I. 2001: At Home on Foreign Meadows: The Reintroduction of two Maculinea Butterfly Species. Ph.D. thesis, Wageningen Agricultural University.
Wynhoff I., Grutters M. \& Van Langevelde F. 2008: Looking for the ants: selection of oviposition sites by two myrmecophilous butterfly species. - Anim. Biol. 58: 371-388.

Received May 9, 2012, revised and accepted July 2, 2012 